\title{
The Impact of Corporate Governance on the Value of the Company in the Egyptian Stock Market
}

http://doi.org/10.21272/bel.3(4).81-90.2019

\author{
Elsayed Mahmoud Elhennawy, ORCID: http://orcid.org/0000-0002-6470-0693
}

Assistant Professor, Department of Accounting, Faculty of Commerce, Damanhour University, Egypt

\begin{abstract}
This research aims to examine the relationship between corporate governance and the value of the company in the stock market. The main purpose of the research is to identify the general framework for corporate governance in the light of the latest standards and studies and analyze the most important studies that have looked at the relationship between corporate governance and performance level of the company, as well as studies that looked at the relationship between corporate governance and the company's value in the stock market. Systematization of literary sources and approaches to solving the problem of company value management showed the absence of comprehensive studies on the impact of corporate governance on the value of the company. The study was conducted on companies registered in the Egyptian stock market, but after the exclusion of financial institutions because they are subject to special rules for disclosure and transparency and oversight, where a sample of non-financial companies will be selected at random. The study period was 2015-2018. The necessary data for the applied research is obtained through the financial statements and reports of the Board of Directors and reports to the audit committees of listed companies in the Egyptian stock market during the period from 2015 and 2018, and the researcher will depend on the method of regression analysis to test the research hypotheses. The research problem stems from the need to answer the following questions: 1. Does corporate governance affect the level of the company's performance? 2. Does the performance of the company affect the value in the stock market? 3. Does corporate governance affect the value of the company in the stock market? The paper presents the results of an empirical analysis, studies the impact of corporate governance on the value of the company in the Egyptian stock market, which showed that there is a positive relationship, but not significant between the corporate governance index and the ratio of market value to book value per share. Besides, the results indicate that there is a positive relationship, but not significant between the corporate governance index and the percentage of Tobin's Q. The results of the study may be useful for companies' managers in the context of developing measures to increase the value of the company in the stock market.
\end{abstract}

Keywords: corporate governance, firm value, and firm performance, stock market, market value.

JEL Classification: G34, D46, L25.

Cite as: Elhennawy, E.M. (2019). The Impact of Corporate Governance on the Value of the Company in the Egyptian Stock Market. Business Ethics and Leadership, 3(4), 81-90. http://doi.org/10.21272/bel.3(4).8190.2019.

(C) The Author, 2019. This article is published with open access at Sumy State University.

\section{Introduction}

Corporate Governance is defined by OECD (2004) as the procedures and processes according to which an organization is directed and controlled. Hence the corporate governance structure specifies the distribution of rights and responsibilities among the different participants in the organization - such as the board of directors, managers, shareholders and other stakeholders - and lays down the rules and procedures for decision-making. Corporate governance became an important topic at all levels and for all institutions and regional and international organizations, after the various financial crises that have occurred in the precipitant companies, especially in developed countries, such as the financial collapse that occurred in a number of Asian and Latin American countries in 1997, and the crisis in Enron company in 2001 as well as the crisis in World com Inc. in 2002. We have raised the current financial crisis, given the substantial progress in the media, interest and ire of the men thought, politics, and investors. Hurried everyone to express their opinion and to express a fear, which is reflected in each of the standard of living and quality of life, two of the most important responsibilities of the contemporary state of institutional failure, and thus began the search in the factors that led to the crisis and the reasons that led to the aggravation and spread 
and their implications for developing countries, some saw it purely financial crisis, while others felt that they manage the crisis, while others are refunded to control the crisis, while the fourth team focused on the lack of governance, especially for large companies (Ball, 2009).

It also shows some of the major companies in the United States and Europe, severe financial crises gripped each other effects machining issue of corporate governance and attached by the transparency and disclosure, and associated with all the confidence between citizens on the one hand, and those major institutions and managed by one hand revealed financial crises the recent collapse of a lot of international companies in the United States and the United Kingdom, as well as European countries, for a lot of cases of corruption, especially financial and accounting corruption, which had a bad impact in many areas, most notably the economic areas where marked by the process of attracting levels adequate capital in these companies a great deal of difficulties due to the incurring of shareholders where the heavy financial losses reflected negatively on the credibility of the investee companies and the capital markets through draws current and potential investors to look for alternative investment outlets, which prompted the approaching relevant on the national and international levels to conduct studies in order to identify the main reasons behind the occurrence of financial crises and to propose ways to protect the rights of shareholders and other stakeholders (Charitou and Louca, 2013).

Agency theory suggests a positive association between corporate governance (CG) and firm value, as good governance improves managerial monitoring and decision-making, as well as reduces managerial expropriation and wastage, and thereby enhances operating performance and market valuation. However, while a number of prior studies (reviewed below) suggest a positive link between CG and firm value, most have been unable to conclusively indicate that good governance actually impacts positively on firm value. A number of reasons may explain the empirically weak association between CG and firm value. First, prior studies have been criticized for methodological weaknesses, with particular regard to inadequately addressing endogeneity problems (Charitou and Louca, 2013), as well as insufficient control for any potential interrelationships between $\mathrm{CG}$ and other possible alternative CG mechanisms. Second, due to the highly labor-intensive nature of collecting firm-level CG data directly from company annual reports (Ball, 2009), prior studies have mostly used subjective analysts of CG ratings, often supplied by rating agencies, such as Credit Lyonnais Securities Asia (CLSA) (Ball, 2009). Thirdly, and crucially, the prior literature notes that CG structures and systems vary across different countries. However, past cross-country studies have not only generally employed subjective analysts of CG ratings, which are standardized so that they fail to reflect unique institutional, cultural and contextual differences in CG mechanisms across different countries, but also such studies remain disproportionately concentrated in the developed countries of Europe and US with comparatively similar institutional settings. However, the role and effectiveness of CG may arguably be different in developing countries, such as South Africa (SA), due to the different institutional, cultural, legal and CG environment (as discussed further below), and as such, the link between CG and firm value can be expected to be different from what has been reported in developed countries.

\section{Literature Review}

The literature on Corporate Governance is vast and still expanding. The researcher aims in this sub-induction and to analyze and evaluate the most important previous studies related to the topic of the search, and derivative research hypotheses in testable in the Egyptian environment image. And in the following manner: In spite of the multiplicity and diversity of the studies that have shown interest in the areas of corporate governance according to their use, the researcher will focus here only on some studies that have shown the relationship between corporate governance and the value of the company in the stock market. For example, Chen et al. (2010) test the impact of corporate governance on the value of the company and that for a sample of companies during the period from 1990 to 2005. The study found that the need for external financing motivated the company to make improvements in the quality of governance systems companies within the company. The study also found that corporate governance greatly affect the value of the company where the quality of corporate governance systems provide indicator to investors that the company is experiencing a lesser extent from the problems of information asymmetry and the problem of interests between management and owners oppose which leads to increasing the wealth of shareholders and the company's value. From another point of view, Cormier et al. (2010) study the corporate governance and information asymmetry between managers and investors through an experiment on a sample of 131 companies representing $80 \%$ of non-financial companies listed in the Toronto Stock Exchange and 44\% of the total companies listed in the Toronto Stock Exchange and those companies belong to the following industries (mining, gold, precious metals, oil and petroleum, paper and consumer products, industrial products, communications, advertising, 
Business Ethics and Leadership, Volume 3, Issue 4, 2019

ISSN (online) - 2520-6311; ISSN (print) - 2520-6761

trade, services, real estate). The study found that corporate governance mechanisms lead to a reduction in the level of information asymmetry between the internal and external parties and thus increase the quality of the financial information contained in the financial reporting level, which reflected positively on the company's market value.

While, Ammann et al. (2011) have investigated the relationship between corporate governance and the value of the company's market and that for a sample of large listed companies in the stock market for the 14 countries of the European Union during the period from 2003 to 2007. And through the test the validity of the following hypothesis: $-\mathrm{H}$ : corporate governance more impacts on the value of the company for the companies that belong to the low competitive industries compared to companies that belong to the highly competitive industries. And even the validity of this hypothesis can be tested depended on each annual View for European companies in the database of GMI during the period from 2003 to 2007 and access to financial data through the World Database scope which led to access to the 3102 Show annually to companies that operate in 14 countries of Europe (Austria, Belgium, Denmark, Finland, France, Germany, Greece, Ireland, Italy, Netherlands, Portugal, Spain, Sweden, United Kingdom). The study data also adopted corporate governance in international governance scale mechanisms of Governance Metrics International (GMI), which began offering special corporate governance data beginning in 2003. The study has relied on this data to create the index of governance, which includes 64 variables; governance covers six groups: the responsibilities of the Board of Directors, financial disclosure and internal controls, shareholder rights, remuneration, market supervision, organization behavior.

The study found that corporate governance is linked directly proportional to the value of the company and that for companies that belong to the non-competitive industries, where the study showed that the governance of good companies for companies that operate in industries without competition in the product market is leading the company to increase capital expenditures and reduce acquisition costs and reduce the degree of diversification within the company. The study found that corporate governance has a positive impact on the value of the company through three channels. Related to the first channel to invest, the study showed a positive relationship between the quality of corporate governance and capital expenditures. Related the second channel of acquisition, the study found that companies that have corporate governance better to spend less money on acquisitions. And related to the third channel of diversification, the study found that companies that have good corporate governance are less likely to get involved in the operations of the value of diversification devastating. On the contrary, Harjoto (2011) tests the impact of internal and external corporate governance and corporate control mechanisms on both the level of the company's commitment to social responsibility and the value of the company. The study found a positive relationship between corporate governance characteristics and commitment to the company's responsibility.

In the same context, Hearn (2011) tests the impact of corporate governance on the market value of properties and companies, through the use of a sample of 37 local companies from West Africa. The study concluded rejection fourth and eighth and accepts the rest of the hypotheses. The study found a positive relationship between the size of the Board of Directors and the value of the company as well as the existence of a positive correlation between the size of the Board of Directors and the reduction of the price, and the existence of an inverse relationship between the retention of the company's founder as chief executive and the value of the company. The study also found a positive relationship between the number of board committees and both of the company's value and reduce. Sar.kma study found an inverse relationship between the separation of the role of the Executive Director on the role of the president of the company and the value of the company. Jung and Zhang (2011) test the effect of ownership structure and corporate governance of the company and the value of that for a sample of listed companies in the stock market in China during the period from 2004 to 2007.

The study concluded that the ownership structure affects the value of the company where the study showed that the state ownership and ownership of shareholders and senior management ownership adversely affect the value of the company's ownership of the institutions and the ownership of the members of the Board of Directors has a positive impact on the value of the company. The study also found that the proportion of independent directors within the Governing Council is linked directly proportional to the value of the company, while dual role of the Executive Director is inversely associated with the value of the company and that the existence of the audit committee within the company is linked directly proportional to the value of the company, but not in a significant degree. Also, Soltani and Ravanmehr (2011) test the relationship between corporate governance and monetary savings and ownership structure and the value of the company through a sample of 75 companies from the Iranian companies listed in the Tehran Stock Exchange during the period from 2002 to 2009. The study found that the value of the company was severely affected by all of the independence of the Board of Directors and the reliance on debt of between governance matter variables, 
ISSN (online) - 2520-6311; ISSN (print) - 2520-6761

which confirms the fact that the companies that have a larger number of outside directors have better management less by managers and internal control which is reflected positively on the stock price. Also, the companies that have the least amount of long-term debt on its balance sheet will be assessed higher. The study also found that increasing the degree of concentration of ownership will be reflected negatively on the share price, which is probably due to the investors, and creditors will criticize the concentration of ownership, and voting rights are exaggerated.

On the other hand, Abbasi et al. (2012) test the relationship between corporate governance and the value of the company for a sample of listed companies in the stock market in Iran during the period from 2002 to 2011. The study found that there was a significant positive correlation between the concentration of ownership and the value of the company as the study found there was no significant relationship between the ownership of enterprises and the value of the company and, finally, the study concluded that there was a significant positive correlation between the dual role of the Executive Director and the independence of the Board of Directors and the value of the company. Also, Bae et al. (2012) test the effect of the control of management on the relationship between corporate governance and the value of the company and that for a sample of non-financial companies listed in the stock market in Korea. The study found that companies with weak corporate governance (large disparity between voting rights and rights to receive cash flows, lower ownership adult shareholders, lower concentration of ownership) more suffering from the decline in value of the company through a period of the financial crisis, but they are more vibrant during the reform period. The study also found that bad news (good) affects the companies that have weak corporate governance negative (positive), the largest of the companies that have a strong degree of governance. The study also found that the stock prices for companies facing a high risk to be less during the financial crisis, but it will be higher during the reform period, compared to companies that have strong governance. Finally, the study found that the incentives adult shareholders for control of the small shareholders is considered a key variable affecting the relationship between corporate governance and the value of the company. The study showed that during the period of the financial crisis increasingly motivated management to control the small shareholders with increased power control management, and decreases with increasing concentration of ownership in their hands while less motivated management to control the reform period .

Dharmapala and Khanna (2012) test the impact of corporate governance on the value of the company and that for the sample of registered in the stock market companies in India during the period from 1998 to 2006. The study found that there were significant positive correlation between the application of corporate governance reforms and the value of the company. The study found that companies that are committed to the application of corporate governance reforms have achieved a significant increase in the value of Tobin's Q as a measure of the value of the company, compared to companies that did not comply with these reforms. The study also showed that there is a large raise to positive corporate governance reforms. Also, Hughes (2012) tested the impact of corporate governance on the market value of the Mexican corporate mechanisms through a sample of 101 non-financial companies registered in the Mexico Stock Exchange during 2007. The study found that companies that are managed by families to be the largest market value in comparison to other forms of management. The study also found that companies that are committed to corporate governance Mexican companies regarding the composition of the Board of Directors be evaluated further and it is probably due to that it can compensate for the lack of protection for investors by creating confidence for investors in the company. In the same context, Ibrahimy and Ahmad (2012) test the relationship between corporate governance and the value of the company and that for a sample of listed non-financial companies in the Malaysia Stock Exchange during the period from 2002 to 2008. The study showed that the concentration of ownership in the hands of a group of shareholders is a tool for the control of management and has great power infrastructure to reflect positively on the value of the company. The study also found that there was a significant positive correlation between the concentration of ownership and the value of the company, which is measured by the accounting measure of the rate of return on equity.

Similarly, Li et al. (2012) test the relationship between the liquidity of the stock, corporate governance and the value of the company and that for a sample of Russian companies listed in the stock market during the period from 2002 to 2009 . The study found that there was a significant positive correlation between the quality of corporate governance and the value of the company where the study showed that the improvement in the level of liquidity of the stock leads to improvements in the quality of corporate governance which is reflected positively on the company's market value. The study of Liu et al. (2012) also aims to test the effect of the structure of corporate governance in China on the value of the company during the global financial crisis, and that for a sample of Chinese companies listed in the stock market. The study found that the stateowned companies, which rely on bank loans less suffering from the decline in value of the company during 
the period of the global financial crisis, but suffered from the decline before the global financial crisis. The study also found that the relationship between ownership of adult shareholders and the value of the company through a period of a global financial crisis takes a U-shaped form which means that the concentration of ownership relieves the financial constraints faced by the company. The study also found that management ownership linked directly proportional to changes in the value of the company for state-owned companies because management ownership leads to an agreement of the interests of management with the interests of minority shareholders and slogan. The study also found that companies that are reviewed by a prestigious center of a review of the company suffered from a slight decrease in the value of the company during the period of the global financial crisis, which means that the quality of the company's disclosure linked directly proportional to the value of the company. Finally, the study found that strong corporate governance plays an important role in alleviating the liquidity risks faced by small shareholders. From another point of view, Renders and Gaeremynck (2012) test the impact of agency problems on the quality and effectiveness of corporate governance whether these problems affect the relationship between the quality of corporate governance systems and the value of the company and that for a sample of European companies during the period from 1999 to 2003. The study concluded that the unit of agency problems is inversely associated with the quality of corporate governance systems, where the study showed that the quality of corporate governance systems incur additional costs of the company, such as loss of private control benefits, and that the vast majority of the shareholders are taking these costs into account when judging the quality of corporate governance. The study also found that the relationship between the quality of corporate governance systems and the value of the company to be more pronounced when the agency problems more acute. The study showed that good corporate governance to be able to mitigate the negative effects of the problems of the agency on the value of the company. Also, Bubbico et al. (2013) test the impact of the quality of corporate governance on the market value of a sample of registered enterprises in the stock market in Italy organized the 34 financial institutions (17 Banks and 17 financial service companies) in 2011. The study found that there was a significant positive correlation between corporate governance and Tobin's Q as a measure of the value of the company, which confirms that corporate governance has a positive influence on the financial value of financial institutions. The study also found that there were significant positive correlation between the return on assets and the value of the company's rate, and the presence of a significant positive correlation between the concentration of ownership and the value of the company where the study showed that an increase in the degree of concentration of ownership helps adult shareholders to exert more effort to the control of management and thus improve the company.

In the same context, Kraff et al. (2013) test the relationship between corporate governance and both the performance and the value of the company and that for the sample of registered Giralomrakih companies in the stock market for 24 different countries during the period from 2003 until 2008. The study found a positive relationship between corporate governance index and earnings per share and dividends as measures of the performance of the stock, which means that companies with better governance have performed better in the stock market and that companies that have good governance that leads to improved performance in the stock market with respect to yield and dividend per share. As the study found that there was a significant positive correlation between governance index and Tobin's $Q$ as a measure of the value of the company and the rate of return on assets and net profit margin as measures of operational performance, which means that good governance has a positive impact on the performance and value of the company.

Similarly, Ntim (2013) tests the relationship between corporate governance and the value of the company and that for a sample of listed companies in the stock market in South Africa during the period from 2002 to 2007. The study concluded that there was a significant positive correlation between the quality of corporate governance practices and the value of the company, which means that companies with better governance achieve greater value in the market, and therefore the listed companies in South Africa, which apply good governance standards, have better performance.

Finally, Wansbeek and Wessels (2014) test the relationship between corporate governance and the value of the company and that for a sample composed of 1551 large US companies during the period from 2000 to 2008 where they got 11242 annual Show. The study relied on corporate governance as an independent variable mechanisms, namely, (the size of the Board of Directors, bonuses of Executive Director, ownership of enterprises, management ownership), as the administration relied on the company's value as a dependent variable was measured by three metrics, namely, Tobin's q as a measure of the value of the company and the rate of return on assets as a measure of value and accounting rate of return on equity as a measure of market value. 
Business Ethics and Leadership, Volume 3, Issue 4, 2019

ISSN (online) - 2520-6311; ISSN (print) - 2520-6761

\section{Research Hypotheses}

In order to evaluate the effects of corporate governance mechanisms on firm value, the following hypotheses are tested:

H1: There is a statistically significant positive relationship between corporate governance index and the level of the company's value in the stock market.

And this hypothesis is derived from the following sub-hypotheses:

- H1a: There is a statistically significant positive relationship between corporate governance index and market capitalization relative to the book value of the shares.

- H2b: There is a statistically significant positive relationship between corporate governance index and the percentage of Tobin's Q.

\section{Data and Methodology}

To analyze the effect of corporate governance mechanisms on firm value, independent and dependent variables are analyzed from two different aspects. According to one of them, these variables are tested among various companies and from the Sample and Data Collection.

In this study, a sample of non-financial firms registered in the Egyptian stock market over the period 20152018 is used. By doing so, our sample comprises data from 90 firms, consisting of 820 year-firm observations. Each firm has to meet specific criteria to be included in the sample:

1. They must close their fiscal year in mid-March (end of the Persian calendar).

2. They must also have data regarding the ownership concentration, percentage of ownership structure

3. and board structure.

4. They must have full financial data for the whole period of investigation.

After examination of the previous conditions of each company possible sample consists of 90 companies to identify and consider this a sufficient size and appropriate to conduct statistical analyses.

\section{Data Collection Method}

The data needed for analysis were taken through the financial statements, and management reports, and reports of audit committees, and report of shareholder structure of listed companies in the Egyptian stock market during the period from 2015 until 2018. Depending on time series of length 4 data years starting from the year 2015 until the year 2018 sample consists of 90 Egyptian non-financial companies, and covering these companies most of the economic activities where companies operating in the areas of telecommunications, chemicals, services and industrial products, cars, construction and building materials, real estate, food and drinks include, care and medicines, gas and oil, household and personal products, media, technology, tourism and leisure, facilities, basic resources.

\section{The Empirical Model}

Single regression analysis is employed to examine the panel data analysis of regression models in the full sample period, from the year of 2015 to 2018. Panel data analysis allows for the consideration of both crosssectional and time series effects in the sample and helps in identifying the sources of possibly mingled effects. The panel generalized least square (GLS) estimated equation for analyzing panel data is given by the following equations:

- The first model: Researcher based on this model verifies the first hypothesis, which tested the relationship between corporate governance index independent variable and the ratio of market value to book value per share as a measure of the value of the company as the dependent variable. As it is assumed that the ratio of market value to book value per share is the index of corporate governance function and the proposed model takes the following form:

$(\mathrm{M} / \mathrm{B})=\beta 0+\beta 1 \mathrm{CGI}+\varepsilon$.

Where: (M/B): ratio of market value to book value per share; CGI: corporate governance index; $\varepsilon$ : random error term.

- The second model: Researcher based on this model verifies the second hypothesis, which tested the relationship between corporate governance index as an independent variable and Tobin's Q ratio as a 
measure of the value of the company as the dependent variable. As it is assumed, the rate of Tobin's Q is the function of the index of corporate governance and the proposed model takes the following form:

$($ Tobin's $\mathrm{Q})=\beta 0+\beta 1 \mathrm{CGI}+\varepsilon$

Where: (Tobin's Q): the proportion of Tobin's Q; CGI: corporate governance index; $\varepsilon$ : random error term.

\section{Variables measurement}

This study aimed at the characterization and measurement of sub-variables of the study and the study with the aim of formulating a model to test the research hypotheses. The variables of the study are divided into subsidiaries and independent variables that can be illustrated as follows: -

\section{The dependent variable}

The study of the variable in the level of the company's value in the stock market. The researcher will depend on a set of metrics to measure the market value of the company, a percentage of market value to book value per share, and the proportion of Tobin's Q.

\section{The independent variable}

The independent variable is the Corporate Governance Index, which includes a set of corporate governance mechanisms. The researcher has designed the index of corporate governance to reflect the increased value of this indicator is the amount of progress the company's commitment towards corporate governance standards.

\section{Results and Discussion}

Designed to study in these sub-Review statistical methods used in the analysis of the data, where adopted by researcher on statistical analysis programs ready package SPSS (Version 17), and after identifying appropriate for normal data and statistical methods and the nature of the assumptions and to analyze the data collected for the sample companies and test hypotheses of the study, where the statistical methods used included simple linear regression analysis method to test the extent of the independent variable's ability to interpret the change in each variable of the dependent variables, in addition to the foregoing, the researcher will use the test Man-Whitney, to test the differences between the two groups, as was the assumption that the moral level of significance level of acceptable equals (05 0.0).

In light of the research hypotheses and build on the results of the statistical analysis that was used in this study will be presented the results interpreted as follows, where the target study in this sub-test research hypotheses to determine the nature of the relationship between corporate governance and the value of the company in the stock market. The researcher based on a simple regression analysis method to test hypotheses of the study and use of Man-Whitney test. This can be illustrated using the results of the testing of hypotheses that statistic as follows:

\section{The first hypothesis test result}

The targeted first hypothesis tested whether there was a statistically significant positive relationship between corporate governance index and the ratio of market value to book value per share. To test this hypothesis researcher formulated a model in which the ratio of market value to book value per share as a measure of the value of the company's variable follower, but is represented in the corporate governance index. As it is assumed that the ratio of market value to book value per share is the index of corporate governance function. The following table shows the results of the regression analysis with regard to the relationship between corporate governance index and the ratio of market value to book value per share as follows:

Table 1. Regression results

\begin{tabular}{|l|c|c|c|c|c|c|c|}
\hline \multirow{2}{*}{ Model } & \multicolumn{2}{|c|}{ Unstandardized Coefficients } & Standardized Coefficients & \multirow{2}{*}{ T } & \multirow{2}{*}{ P-Value } & \multirow{2}{*}{ R Square } & \multirow{2}{*}{ F } \\
\cline { 2 - 9 } & B & Std. Error & Beta & .761 & .449 & .007 & .579 \\
\hline CGI & .896 & 1.177 & .081 &
\end{tabular}

a. Dependent Variable: M/B

Source: Elaborated by the author

Clear from the above table that the coefficient of determination (R2) of (0.007) means that the ratio is explained by the corporate governance index of the dependent variable and the ratio of market value to book value per share is approximately $0.7 \%$. With regard to the suitability of the regression model has reached the value of (F) calculated (0.579) at the moral level of 0.449, which means that the model as a whole does not have the statistical sign by high. As a result, the regression analysis indicates that the estimated model coefficient ( $\beta 1$ ) for the index of corporate governance takes a positive value, but not significant, since the 
ISSN (online) - 2520-6311; ISSN (print) - 2520-6761

value of the $(\mathrm{T})$ test is equal to 0.761 and 0.449 level of significance. Which supports the rejection of the third hypothesis of these assumptions and therefore we can say that there is a positive relationship, but not significant between the governance index and the ratio of market value to book value per share, and based on those results can reject the first hypothesis, which stipulates the presence of a statistically significant positive relationship between corporate governance index of companies and the ratio of market value to book value per share.

\section{The second hypothesis test result}

The second hypothesis aimed to test whether there was a statistically significant positive relationship between corporate governance index and the percentage of Tobin's Q. To test this hypothesis a model was formulated in which the researcher Tobin's $Q$ ratio is a measure of the value of the company's variable follower, As it is assumed, the rate of Tobin's Q is the index of corporate governance function. The following table shows the results of the regression analysis with regard to the relationship between corporate governance index and Tobin's Q ratio, as follows:

Table 2. Regression results

\begin{tabular}{|l|c|c|c|c|c|c|c|}
\hline \multirow{2}{*}{ Model } & \multicolumn{2}{|c|}{ Unstandardized Coefficients } & Standardized Coefficients & \multirow{2}{*}{ T } & \multirow{2}{*}{ P-Value } & \multirow{2}{*}{ R Square } & \multirow{2}{*}{ F } \\
\cline { 2 - 8 } & B & Std. Error & Beta & .761 & .449 & .007 & .579 \\
\hline CGI & .224 & .294 & .081 &
\end{tabular}

a. Dependent Variable: Tobin's Q

Source: Elaborated by the author

It is clear from the above table that the coefficient of determination (R2) of (0.007) means that the ratio is explained by the corporate governance index of the dependent variable Tobin's $\mathrm{Q}$ ratio is approximately $0.7 \%$. With regard to the suitability of the regression model has reached the value of $(\mathrm{F})$ calculated $(0.579)$ at the moral level of 0.449 , which means that the model as a whole does not have the statistical sign by high.

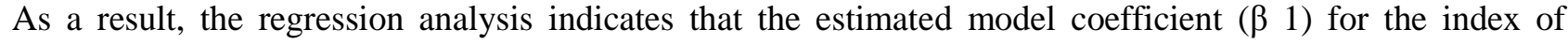
corporate governance takes a positive value, but not significant, since the value of the (T) test is equal to 0.761 and 0.449 level of significance. Which supports the rejection of the fourth hypothesis of these assumptions and therefore we can say that there is a positive relationship, but not significant between the governance index and the percentage of Tobin's Q, and based on those results can reject the second hypothesis, which stipulates the presence of a statistically significant positive relationship between corporate governance index and the percentage of Tobin's Q.

\section{Conclusion and Discussion}

This research aims at examining the relationship between corporate governance and the value of the company in the stock market. The study also aimed to test the impact of the level of the company's performance on the previous relationship as a mediating factor, using a sample of non-financial companies listed in the Egyptian stock exchange for a period of four years 2015-2018. The study was conducted on companies registered in the Egyptian stock market, but after the exclusion of financial institutions because they are subject to special rules for disclosure and transparency and oversight, where a sample of nonfinancial companies will be selected at random. And You will get the necessary data for the applied research through the financial statements and reports of the Board of Directors and reports to the audit committees of listed companies in the Egyptian stock market during the period from 2015 and 2018, and the researcher will depend on the method of regression analysis to test the research hypotheses. The research presents the results of an empirical analysis, studies the impact of corporate governance on the value of the company in the Egyptian stock market, which showed that there is a positive relationship, but not significant between the corporate governance index and the ratio of market value to book value per share, and the results indicate that there is a positive relationship, but not significant between the corporate governance index and the percentage of Tobin's Q.

\section{Further Research}

A further study may be carried out including more factors in corporate governance mechanisms and by expanding its scope to other industries of Egypt for better understanding and generalizing of the findings. We focused on corporate governance and the firm's value. We recognized that better corporate governance is advocated for reasons aside from enhancing the firm's value. It is plausible that governance factors unrelated 
Business Ethics and Leadership, Volume 3, Issue 4, 2019 ISSN (online) - 2520-6311; ISSN (print) - 2520-6761

to firm value are important for other purposes. Future research should examine corporate governance in these and in other contexts.

\section{References}

1. Abbasi, A., Kalantari, E., and Abbasi, H. (2012). Impact of Corporate Governance Mechanisms on Firm Value Evidence from the Food Industry of Iran. Journal of Basic and Applied Scientific Research, 2(5), 4712-4721. ISSN 2090-4304.

2. Armstrong, S.A., Guay, W.R. and Weber, J. (2010). The role of information and financial reporting in corporate governance and debt contracting. Journal of Accounting and Economics, 5(0), 179-234. https://doi.org/10.1016/j.jacceco.2010.10.001.

3. Bae, K., Seung, Baek, J., Koo Kang, J., and Lin Liu, W. (2012). Do controlling shareholders' expropriation incentives imply a link between corporate governance and firm value? Theory and evidence. Journal of Financial Economics, 105, 412-435. http://dx.doi.org/10.1016/j.jfineco.2012.02.007.

4. Brickley, J., and Zimmerman, J. L. (2010). Corporate governance myths: Comments on Armstrong, Guay, and Weber. Journal of Accounting and Economics, 50, 235-245. https://doi.org/10.1016/j.jacceco.2010.10.002.

5. Bubbico, R., Giorgino, M. and Monda, B. (2013). The Impact of Corporate Governance on the Market Value of Financial Institutions-Empirical Evidences from Italy. Banks and Bank Systems, 7(2). Available at SSRN: https://ssrn.com/abstract=2119497.

6. Charitou, A., and Louca, C. (2013). Corporate Governance, Agency Problems, and Firm Performance: Empirical Evidence from an Emerging European Market. Available at SSRN: https://ssrn.com/abstract=2221612 or http://dx.doi.org/10.2139/ssrn.2221612.

7. Chen, W., Chung, H., Ling Hsu, T. and Wu, S. (2010). External Financing Needs, Corporate Governance, and Firm Value. Corporate Governance: An International Review, 18(3), 234-249. https://doi.org/10.1111/j.1467-8683.2010.00801.x.

8. Dharmapala, D., and Khanna, V. (2012). Corporate Governance, Enforcement, And Firm Value: Evidence from India. Journal of Law, Economics, and Organization, Oxford University Press, 29(5), 1056-1084. http://citeseerx.ist.psu.edu/viewdoc/download?doi=10.1.1.380.8841\&rep=rep1\&type=pdf.

9. Harjoto, M. A. (2011). Corporate Governance and Firm Value the Impact of Corporate Social Responsibility. Journal of Business Ethics, 103(3), 351-383. https://doi.org/10.1007/s10551-011-0869-y.

10.Hearn, B. H. (2011). The impact of corporate governance measures on the Performance of West African IPO firms. Emerging Markets Review, 12, 130-151. https://doi.org/10.1016/j.ememar.2011.02.004.

11.Hughes, J. P. (2012). The value effect of corporate governance: Evidence from Mexico. Working paper. Available at: http://www.ssrn.com, pp. 1-33. DOI: 10.2139/ssrn.1748624.

12.Ibrahimy, A., and Ahmad, R. (2012). Blockholders, Corporate Governance and the Value of the Firm: A Panel Data Analysis of Malaysian Non-financial Companies. Financial Markets \& Corporate Governance Conference. Available at SSRN: https://ssrn.com/abstract $=1980166$ or http://dx.doi.org/10.2139/ssrn.1980166.

13.Jung-Wha, J., and Zhang, Z. (2011). Ownership Structure, Corporate Governance and Firm Value: Evidence from Chinese Listed Companies. Finance and Corporate Governance Conference, 1-34. Available at SSRN: https://ssrn.com/abstract=1726592 or http://dx.doi.org/10.2139/ssrn.1726592.

14.Krafft, J., Qu, Y., Quatraro, F. and Ravix, J.L. (2013). Corporate governance, value and performance of firms: New empirical results on convergence from a large international database. Industrial and Corporate Change, 22(3), 361-397. DOI:10.1093/icc/dtt007.

15.Li, W., Chen, C.C. and French, J.J. (2012). The relationship between liquidity, corporate governance, and firm valuation: Evidence from Russia. Emerging Markets Review, 13, 465-477. DOI:10.1016/j.ememar.2012.07.004.

16.Liu, C., Uchida, K. and Yang, Y. (2012). Corporate governance and firm value during the global financial crisis: Evidence from China. International Review of Financial Analysis, 21, 70-80. https://doi.org/10.1016/j.irfa.2011.11.002.

17.Nayeri, N., and Salehi, M. (2013). Agency Costs in Islamic Countries: Evidence from Iran. The Journal of Accounting Research \& Audit Practices, XII(2), 68-77. Persistent link: https://EconPapers.repec.org/RePEc:icf:icfjar:v:12:y:2013:i:2:p:68-76.

18.Ntim, C.G. (2013). An Integrated Corporate Governance Framework and Financial Performance in South African Listed Corporations. Available at: http://mpra.ub.uni-muenchen.de, No. 45805, April, pp. 1-34. https://doi.org/10.1111/j.1813-6982.2011.01316.x. 
19.Renders, A., and Gaeremynck, A. (2012). Corporate Governance, Principal-Principal Agency Conflicts, and Firm Value in European Listed Companies. Corporate Governance: An International Review, 20(2), 125-143. https://doi.org/10.1111/j.1467-8683.2011.00900.x.

20.Saibaba, M. D., and Ansari, V. A. (2013). Audit Committees, Board Structures and Firm Performance: A Panel Data Study of BSE 30 Companies. The Journal of Accounting Research \& Audit Practices, XII(2), 19-30. Available at SSRN: https://ssrn.com/abstract=2278133.

21.Song, C. J., Thomas, W. B. and Yi, H. (2010). Value Relevance of FAS No. 157 Fair Value Hierarchy Information and the Impact of Corporate Governance Mechanisms. The Accounting Review, 85(4), 1375-1410. https://doi.org/10.2308/accr.2010.85.4.1375.

22. Wessels, R.E., and Wansbeek, T. (2014). What is the Relation (if any) Between a Firm's Corporate Governance Arrangements and its Financial Performance? Industrial Organisation, January, No. 4599, pp. 1-33. Available at SSRN: $\underline{\text { https://ssrn.com/abstract=2371051 }}$ or http://dx.doi.org/10.2139/ssrn.2371051.

23.Zgarni, I., Halioui, K., and Zehri, F. (2014). Do the Characteristics of Board of Directors Constrain Real Earnings Management in Emerging Markets? Evidence from the Tunisian Context. The IUP Journal of Accounting Research \& Audit Practices, XIII(1), 46-62. Available at SSRN: https://ssrn.com/abstract=2485001. 